\title{
Job Insecurity and Turnover Intentions among Banking Sector Employees: The Moderating Role of Organizational Support and Ethical Leadership
}

\author{
Prince Addai1 ${ }^{\circledR}$, Rejoice Mottey ${ }^{2} \unrhd$, Michelle Afrifah ${ }^{3}$, Augustine Osei Boakye \\ Department of Management and Human Resources, Faculty of IT Business, Ghana \\ Communication Technology University ${ }^{1,2,3,4}$ \\ * Corresponding author: paddai@gctu.edu.gh
}

\begin{abstract}
Article History
Received 2021-11-12

Revised 2021-12-02

Revised 20201-12-11

Accepted 2021-12-17

Published 2022-01-01
\end{abstract}

\section{Keywords}

Job insecurity

Ethical leadership

Organizational support

Turnover intentions

Banking institutions
Purpose - Job insecurity exerts a significant impact on turnover intentions among employees. The association may be partly due to the influence of organizational support and the ethicality of leaders. However, there is a shortage of studies on the ameliorating role of organizational support and ethical leadership in the nexus between job insecurity and turnover intentions. Thus, the purpose of this study is to examine the nexus between job insecurity and turnover intentions among banking sector employees. The moderating role of organizational support and ethical leadership on the underlying relationship was assessed to achieve this.

Design/methodology/approach - One hundred and sixty (160) banking sector employees were conveniently selected to participate in the study. The sample consisted of female $(\mathrm{n}=92)$ and male $(\mathrm{n}$ $=68$ ) employees, ranging from 23 to 49 years. Standardized measures were used in soliciting respondents' demographic characteristics, perceived job insecurity, ethical leadership, organizational support, and turnover intentions. Data were analyzed using regression analysis.

Findings - Results revealed a significant positive correlation between perceived job insecurity and turnover intentions. Organizational support and ethical leadership also moderated the association between job insecurity and turnover intentions. The influence of job insecurity on turnover intentions minimizes when management provides the needed support and favorable climatic conditions.

Originality/value - In general, the study highlights the importance of organizational support and ethical leadership in lessening the impact of job insecurity on turnover intentions. 


\section{Introduction}

Recently, the interest among researchers and employers in the problems of job insecurity has increased tremendously, owing to the rate of collapse of jobs and mergers and acquisitions in the Ghanaian banking sector (Okyere-Kwakye et al., 2018). This has created numerous challenges for organizations that affect the organization's effectiveness. Turnover is one of the most excellent human resource challenges an organization faces and is very destructive for organizational effectiveness (Gyensare et al., 2015). The violent nature of turnover poses a challenge for researchers in assessing the factors that ensure high retention among employees. The problem associated with setting turnover in the short term makes it prudent to evaluate the intention associated with turnover, which is a significant predictor of actual turnover. Studies have also shown that certain organizational practices and leadership determine the extent to which employees may react to insecurity surrounding the banking sector (Acha, 2012; Addai et al., 2018).

Globally, the world economy is more dynamic and has received increased interest in the banking sector (Addai et al., 2018). Each bank has to grapple with the difficulties that constantly change the decisions and projections of the bank (Acha, 2012). Considering the banking sector in Ghana, the situation is dire due to increased competition among banks, increase in the fund of stakeholders, bankruptcy, changes in management, and frequent increment in the required minimum capital (Puni et al., 2018). According to Okyere-Kwakye et al. (2018), the frequent failure of banks in Ghana has driven employees in the banking sector to seek alternative jobs, thus increasing the degree of turnover intentions (Ofori, 2020). The collapse of two local banks (UT and Capital Banks) in 2017 and the recent consolidation of five other banks (UniBank, Construction, Royal Bank, Sovereign, and BEIGE) by the Bank of Ghana has fueled the feeling of insecurity, creating a higher level of turnover intentions (Puni et al., 2018).

Turnover intention is a measurement of employees' intent to voluntarily leave their jobs or the organization's intent to remove employees from their current positions (Amponsah-Tawiah et al., 2015). According to Dwomoh and Frempong (2017), the chief determinant of turnover intentions among employees in the banking sector is the feeling of job insecurity resulting from the frequent collapse of banks. The feeling of job insecurity among employees has grown more severe and more rampant in the Ghanaian banking sector (Dwomoh, \& Frempong, 2017). Economic conditions have led to a solid reconstructing initiative resulting in regular layoffs and changes in conditions of employment in the banking sector. Consolidation of Banks has also broken out in the banking sector as the new capital requirement by the central bank has pressured banks to put plans in place to acquire or merge strategic stakes in other banks (Akosah et al., 2018). The recent increase in capital requirement has triggered some mergers and acquisitions. Mergers also can make employees redundant, leading to layoffs and turnover intentions (Akosah et al., 2018).

The feeling of job insecurity leading to withdrawal responses such as turnover intentions can be influenced by managerial support and the perceived ethicality of leaders (Addai et al., 2018). Thus, managerial support and ethical leadership are essential, influential factors of job insecurity and turnover intentions. Employees perceive general beliefs about the degree to which their employers care about their welfare and support them on issues related to the job and outside the job (Osei Boakye et al., 2021; Wayne, Shore \& Liden, 1997). When employees perceive a higher level of support from management, it results in feelings of obligations and greater affective attachment to the organization (Osei Boakye et al., 2021; Wayne et al., 2007). In this sense, employees disregard the insecurity surrounding the job and stick to the organization since managerial support creates a sense of importance to the organization.

Besides managerial support, ethical leadership is a significant determinant of how employees may react to insecurity surrounding the banking sector. Ethical leadership denotes "the demonstration of normatively appropriate conduct through personal actions and interpersonal relationships, and promoting such conduct to 
followers through two-way communication, reinforcement, and decision-making” (Rubin et al., 2010, p.216). Ethical leaders demonstrate fairness, selflessness, civility, and respect for subordinates (Northouse, 2013). Ethicality in leadership generates involvement and motivates employees in organizations. According to Dinc and Nurovic (2016), the fair treatment of subordinates and the engagement in ethical principles by ethical leader's influence employees to avoid withdrawal responses associated with perceptions of job insecurity.

The proliferation of mergers and acquisitions has increased studies on turnover intentions and layoffs in Ghana. However, job insecurity as a major stressor of mergers and acquisitions and perceived layoffs has been ignored to some considerable extent by researchers in Ghana. Moreover, much of the extant research has mainly adopted the main effects approach, exploring the linkage between job insecurity and turnover intentions (Dwomoh \& Frempong, 2017; Lee et al., 2017) and not concerted on various factors that can facilitate the influence of job insecurity on turnover intentions. Studies emanating from the West (Balz \& Schuller, 2018; Lee \& Jeong, 2017) on the sequels of job insecurity have progressed beyond the major effect relationship and have started exploring other clarifying factors. These studies have pointed out a need to explore other prevailing variables to mitigate the nexus between job insecurity and turnover intentions. However, no study has examined the influential role of ethical leadership and organizational support on the association between the underlying relationship in Ghana. Therefore, the present research fills the gap in literature relating to the burgeoning rate of insecurity associated with the banking industries.

Based on the above, this study's objectives are to:

- assess the impact of job insecurity on turnover intentions

- Establish organizational support and turnover intentions as explanatory factors moderating the correlation between job insecurity and turnover intentions.

\section{Literature Review}

\section{Turnover Intention}

Turnover, the aggregate of employees who leave a given organization in a given period, is a severe human resource concern for every organization (Alghamdi, 2018). Aside from the monetary aspect of replacing competent employees, organizations go through difficult times for their new employees to reach the level needed to achieve organizational effectiveness. Before employees quit an organization, they first conceive the intention to do so (Jimenez et al., 2017). To seek remedies for turnover, there is the need to consider turnover intentions which are the final step before employees quit the organization (Bam, 2010). Turnover intention is the wish of employees to resign from their positions (Addai et al., 2018). Turnover can be voluntary or involuntary (Lee \& Jeong, 2017). Voluntary turnover intention is where the employee intentionally wants to quit his current position due to perceived injustice. This perceived injustice may include job insecurity, low salary, poor treatment from leaders, etc. Involuntary turnover deals with "the measurement of whether the organization in question plans to remove employees from their current position, causing the turnover" (Gyensare et al., 2015, p. 781). This can happen due to downsizing, mergers and acquisitions, or economic pressures. When employees perceive looming involuntary turnover, they also think of voluntarily exiting the organization (Attiah \& AbouDahab, 2017). According to Lee and Jeong (2017), the voluntary turnover intention is more detrimental to the effectiveness of the organization, and thus this study assessed voluntary turnover among employees.

\section{Job Insecurity and Turnover Intentions}

The incessant layoff of employees in Ghana due to mergers and acquisitions, organizational restructuring, financial savings, and changing work practices in banking institutions to remain competitive has resulted in job 
insecurity (Cascio, 1999). Accordingly, one of the major work-related stressors in the banking sector affecting the growing number of employees is perceived job insecurity (Alghamdi, 2018). Job insecurity, according to Sverke and Hellgren (2002), deals with "the overall concern about the continued existence of the job in the future" (p. 243). Exposure to job insecurity is related to varying negative employee attitudes such as turnover intention. The influence of job insecurity on turnover intentions can be explained with psychological contract theory (De Cuyper \& De Witte, 2006). Psychological contracts are an individual's belief systems regarding the mutual obligation between the employee and the organization. Employees accept a position in an organization believing that the work is secured. In return for loyalty and determination, employees need to feel that their job is secured with development and career progression possibilities. When the expectations are not met, "the psychological contract is violated, and a likely result is a feeling of betrayal" (Lee \& Jeong, 2017, p. 531). In this sense, employees will reciprocate by quitting the organization (turnover intentions).

Researches indicate that job insecurity may have a critical short and long-term effect on the organization. Turnover intentions that can lead to counterproductive work behaviors have short-term consequences for job insecurity. An empirical study by Alghamdi (2018) also revealed that job insecurity and turnover intentions are positively correlated among the Electricity Company of Ghana employees. Similarly, the study by Lee and Jeong (2017) found that job insecurity has a detrimental effect on turnover intentions among employees in South Korea. On the contrary, a study by Trimble (2006) found no significant connection between job insecurity and turnover intentions. According to Trimble, job insecurity is just a subjective feeling, and that the objective treatment of individual employees would determine whether employees wish to remain part of the organization over a foreseeable period or not. These inconsistent findings make it prudent for further research into the connection between job insecurity and turnover intentions. Consequently, it is predicted that:

\section{$H_{1:}$ Job insecurity significantly predicts turnover intentions}

\section{Organizational Support Moderating Job Insecurity-Turnover Intention Relationship}

According to Lim (1996), perceived job insecurity connects to withdrawal response (example, turnover intentions), but the support provided by management plays a pivotal role in the underlying relationship. Balz and Schuller (2018) defined organizational support as "the degree to which employees believe that their organization values their contributions and cares about their well-being and fulfills socioemotional needs" (p. 25). Organizational support can create a felt responsibility to care among employees to assist management in achieving its objectives (Attiah \& Dahab, 2017). According to the norm of reciprocity, if employees perceive support from their employers, they will emotionally commit themselves to the organization with a high possibility of job performance and a low level of turnover intentions (Balz \& Schuller, 2018).

Empirically, Gunalan and Ceylan (2015) found that managerial support lessens the association between job insecurity and turnover intention. This means that the extent to which job insecurity influences turnover intentions depends on certain managerial factors such as support. More so, Jiménez et al. (2017) found that organizational support moderates the association between job insecurity and turnover intentions. Additionally, various researchers have advanced that organizational support determines the extent to which employees' perceptions about the work context influence their attitudes and behavior (Balz, \& Schuller, 2018; Lim, 1996). Thus, the support employees receive for perceived job insecurity to predict turnover intentions plays a significant role. However, Bam (2010) found that organizational support does not moderate the nexus between job insecurity and turnover intentions.

Indeed, organizational support has been predicted to be an influential factor in the association between job insecurity and turnover intentions. However, empirical research is limited in literature, particularly in Ghana. This makes it prudent to conduct additional studies to examine the role of organizational support on the association between job insecurity and turnover intentions. It is, therefore, predicted that: 


\section{$\mathrm{H}_{2}$ : Organizational support moderates the relationship between job insecurity and turnover intention relationship}

\section{Ethical Leadership Moderating Job Insecurity-Turnover Intention Relationship}

Ethical leadership is "the demonstration of normatively appropriate conduct through personal actions and interpersonal relationships, and promoting such conduct to followers through two-way communication, reinforcement, and decision-making" (Rubin et al., 2010, p.216). Ethical leadership possesses productive organizational characteristics such as fairness, decency, selflessness, altruism, integrity, and respect for others. A moral leader serves as a role model to employees, motivating them to engage in productive work behaviors.

Ethical leadership augments employees' perception of the organization and related issues by making employees perceive fairness and feel valued (Silla et al., 2010). Ethical leaders provide a sense of fairness and self-respect that changes employees' negative perceptions, such as insecurity in predicting employees' intention to quit. While enough studies have been done on the individual relationships between ethical leadership, job insecurity, and turnover intentions, there is a scarcity of studies on the moderating role of ethical leadership on the association between job insecurity and turnover intentions. Few studies dwell on the various principles of ethical leadership without considering ethical leadership as a unitary construct. A study by Ekmekci and Karapinar (2015) revealed that the principles of ethical leadership influenced the relation between job insecurity and turnover intentions. Similarly, Tatar and Erdil (2017) found that perceived fairness and altruism, which are core principles of ethical leadership, moderate the relation between job insecurity and turnover intentions. It is contended that if leaders hold higher levels of ethical ideals, then the negative perception of the atmosphere within the organization (perceived insecurity) will change, thus improving employees' attitudes and retention (Gyensare et al., 2015).

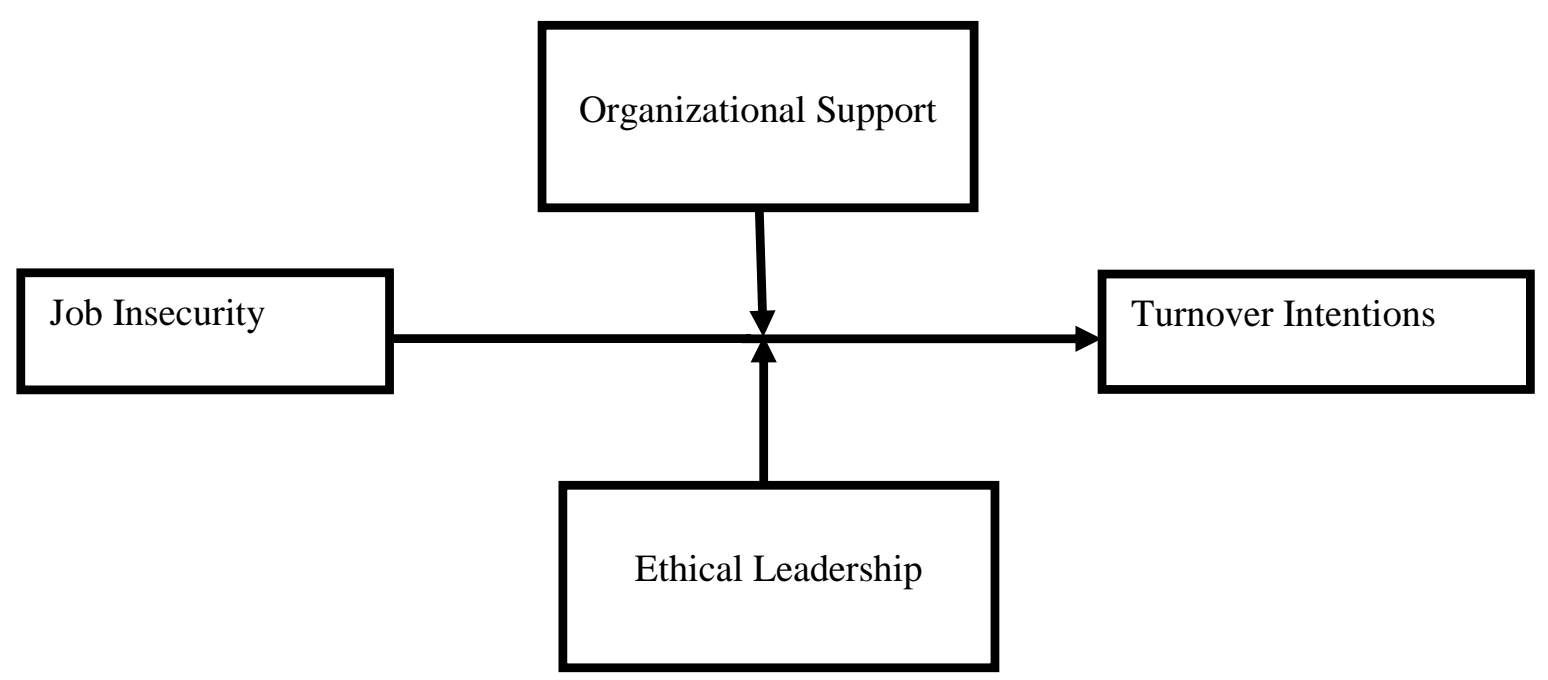

Figure 1: Hypothesized framework of organizational support and ethical leadership as moderators of the association between job

$$
\text { insecurity and turnover intentions }
$$

In this study, ethical leadership serves as the moderator to explain the direct association between job insecurity and turnover intentions. It vies that the nexus between job insecurity and turnover intentions will be determined by the behavior and attitudes of their leaders. As depicted by Attiah and Dahab (2017), the feelings and perceptions of employees that predict their work-related attitudes and behaviors are determined by how ethical their leaders are. This means that ethical leadership can serve as an explanatory mechanism for the association between perceived job insecurity and turnover intentions. The researchers consequently predicted that ethical leadership can moderate relationship between job security and turnover intentions. 


\section{$H_{3:}$ Ethical leadership moderates job insecurity and turnover intention relationship}

According to psychological contract theory (Rousseau, 2011), an employee joins an organization with predetermined ideas about their responsibilities and the obligations of the employers in return. Employees who think that the employer is not fulfilling their responsibilities and duties are more likely to reduce their commitment to the organization. Inability to fulfill one's requirements naturally increases the suspicions of the other and leads to a weakening in the perceived value in the arrangement of the employment. The theory again predicts that an employee may show more negative reactions to the organization if minor interactions and support (lack of managerial support) between the individual employee and the employer. This means the negative consequences will reduce if there are higher interactions and support between the employee and the employer. Thus, the following framework can be derived from the theory.

\section{Methodology}

\section{Research Design}

This study employed a cross-sectional design. The cross-sectional design is a non-experimental method that collects data at a point in time to draw inferences about a specific population of interest (Addai et al., 2018). This design was appropriate because many data were gathered reasonably short.

\section{Participants}

Employees at Zenith and Barclays (Absa) Banks in Greater Accra participated in the study. Convenient sampling was used in deciding the participants for the study. In research work, determining the sample size is crucial due to ethical and economic reasons. It is prudent to ensure that the sample size is large enough to contribute enough research knowledge. The sample size was based on Tabachnick and Fidell (1996) formula which proposes $\mathrm{N}>50+8(\mathrm{p})$, where $\mathrm{p}$ represents the number of predictions. With three (3) predictions, the sample size was projected to be more than 74 . Based on this, one hundred and sixty $(n=160)$ respondents were used. However, 160 respondents were targeted to cater to the nonresponse rate.

\section{Measures}

\section{Job Insecurity}

This was assessed with the Job Insecurity Scale (JIS, Ashfold, Lee \& Bobko, 2001). The JIS is a 12-item inventory with 5-point Likert options ranging from "strongly disagree" to "strongly agree," with an alpha value of .92. Some items in the JIS include "I think that I will be able to continue working here" and "I am worried about keeping my job." Possible scores ranged from 12 - 60, with higher scores reflecting higher levels of job insecurity. The present study reported an alpha value of .89 .

\section{Organizational Support}

The present study reported a Cronbach alpha of .91 for this study. It was measured with the Organisational Support Scale (OSS; Eisenberger et al., 1986) with Cronbach alpha of .87. The short version of the OSS, which is a unidimensional scale of 8 items, with 4-point Likert options ranging from "strongly disagree" to "strongly agree" was used. Sample items of the scale include: "In my organization, management identify skills we need and help to develop it," and "In my organization, management helps the employees in all issues relating to the job and outside the job". The possible maximum and minimum scores that the scale attracts are 32 and 8 respectively, with higher scores reflecting better organizational support.

\section{Ethical Leadership}

This was measured using the Multifactor Ethical Leadership Inventory (MELI) developed by Brown and Mitchel (2010). The MELI is a ten (10) item scale with a Cronbach's alpha of .84. Some items include; "My 
leader conducts his/her personal life ethically" and "My leader defines success not just by results but also by how they are obtained." The MELI is responded on 5-point Likert options ranging from "strongly disagree" to "strongly agree." The scale attracts possible total scores from $0-50$. Higher scores reflect higher ethicality in leadership.

\section{Turnover Intentions}

Data on turnover intentions was solicited using the Turnover Intention Inventory (TII) developed by Cammann et al. (1979), with a Cronbach alpha of .82. The TII is a 10-item unidimensional scale that reflects the respondent's voluntary intention to exit the organization. Sample items included "It is likely that I will actively look for a new job in the next year" and "It would take very little change in my present circumstances to cause me to leave this organization." Responses of the scale are on a 5-point Likert ranging from "strongly disagree" to "strongly agree." Higher scores on the scale reflected a higher intention to exit. The current study found a Cronbach alpha of .88 for the TII.

\section{Procedure}

Data was collected in the presence of the authors using a physical survey. Introductory letters were presented to the selected banking institutions to inform them about the possibility of using their employees for the study. With approval from the management, employees were pre-informed about the purpose, and their voluntary consent was sought to participate in the study. Respondents who consented to the study were assured of confidentiality and anonymity. The scales were then administered to the respondents in an envelope. It took approximately 30 working days to gather the data.

\section{Results}

\section{Demographic characteristics of the respondents}

Of the 160 employees who took part in the study, the majority (57\%) of them were females. The respondent's age range was between 23 and 49 years, with an average of 32.60 years. Most of the respondents $(66.3 \%)$ had at least a first degree in educational background. Most (61.3\%) of the respondents were also married (see Table 1).

Table 1: Demographic Distribution of Respondents $(n=160)$

\begin{tabular}{lcc}
\hline Demographics & Frequency (F) & Percentage (\%) \\
\hline Gender & 68 & 42.6 \\
$\quad$ Male & 92 & 57.4 \\
Females & & \\
Age & 25 & 15.6 \\
$\quad$ Below 25 Years & 39 & 24.4 \\
25 - 30 Years & 56 & 35.0 \\
31 - 40 Years & 40 & 25.0 \\
$\quad$ Above 40 Years & & \\
Educational & 15 & 9.3 \\
$\quad$ Up To Senior High School & 39 & 24.4 \\
Diploma & 82 & 51.3 \\
Degree & 24 & 15.0 \\
$\quad$ Postgraduate & & \\
Marital Status & 98 & 61.3 \\
$\quad$ Married & 62 & 38.7 \\
Single & &
\end{tabular}



Work Experience
At least 5 years
32
20.0
$6-9$ years
44
27.5
$10-15$ years
49
30.6
Above 15 years
35
21.9

\section{Descriptive Statistics}

Table 2: Inter-correlation among Variables $(n=160)$

\begin{tabular}{|c|c|c|c|c|c|c|}
\hline Variable & 1 & 2 & 3 & 4 & 5 & 6 \\
\hline 1. Age & - & & & & & \\
\hline 2. Tenure & -.03 & - & . & & & \\
\hline 3. Insecurity & -.10 & .15 & $(.86)$ & & & \\
\hline 4. Support & -.04 & -.12 & $-.24^{* *}$ & $(.92)$ & & \\
\hline 5. Ethical Leadership & -.02 & -.10 & $-.33^{* *}$ & $.28^{* *}$ & $(.85)$ & \\
\hline 6. Turnover & -.05 & $.29^{* *}$ & $.43^{* *}$ & $-.41^{* *}$ & $-.32^{* *}$ & $(.88)$ \\
\hline
\end{tabular}

From Table 2, it can be observed that job insecurity correlated negatively with organizational support $(r=-.24$, $p<.01)$ and ethical leadership $(r=-.33, p<.01)$ but positively associated with turnover intentions $(r=.43, p<.01)$. Organizational support was also associated positively with ethical leadership $(r=.28, p<.01)$ but negatively with turnover intentions $(r=.41, p<.01)$. Ethical leadership correlated negatively with turnover intentions $(r=-.32$, $p<.01)$.

\section{Hypotheses Testing}

Hypothesis 1: Job insecurity will significantly predict turnover intentions. The simple regression was used in analyzing this hypothesis (see Table 3). As displayed in Table 3, job insecurity significantly and positively predicted turnover intentions $(\beta=.426, p<.001)$. Perceived job insecurity accounted for $18.2 \%$ of the total difference in expounding turnover intentions $\left(\mathrm{R}^{2}=.182, F_{(1,159)}=26.183, p<.001\right)$. This supports the first prediction.

Table 3: Simple Regression of Job Insecurity Predicting Turnover Intentions

\begin{tabular}{lccccc}
\hline Model & $\mathrm{B}$ & Std. Error & $\mathrm{R}^{2}$ & $F$ & $\beta$ \\
\hline (Constant) & 3.659 & 7.724 & & & \\
Job Insecurity & 0.437 & 0.085 & 0.183 & 26.183 & $0.426^{* *}$ \\
\hline
\end{tabular}

$* * p<0.01$

Hypotheses 2 and 3 respectively proposed that "Organizational support moderates the relationship between job insecurity and turnover intention relationship" and "ethical leadership moderates the relationship between job insecurity and turnover intention relationship." The hierarchical regression model for testing the moderating effect Baron and Kenney (1986) proposed was used to analyze these two hypotheses. The predictor (job insecurity) was entered in this model in the first step. In contrast, the moderator (Organizational support or ethical leadership) was entered in the second step to forecast the outcome variable (turnover intentions). The interaction between the predictor and the moderator (job insecurity and Organizational support) (job insecurity and ethical leadership) was entered in the last step. The results for the hierarchical regression model are offered in Tables 4 and 5. 
Table 4: Hierarchical Regression showing Organizational support as a moderator of the association between Job Insecurity and Turnover Intentions

\begin{tabular}{lcccccc}
\hline Steps & $\beta$ & $\mathrm{t}$ & $\mathrm{R}^{2}$ & $\Delta \mathrm{R}^{2}$ & $\mathrm{~F}$ & $p$ \\
\hline $\begin{array}{l}\text { Step 1 } \\
\text { Job Insecurity }\end{array}$ & .426 & 5.117 & .182 & .182 & 26.183 & .000 \\
$\begin{array}{l}\text { Step 2 } \\
\quad \text { Org Support }\end{array}$ & -.326 & -4.030 & .281 & .099 & 22.904 & .000 \\
$\begin{array}{l}\text { Step 3 } \\
\quad \text { Job Insecurity } \times\end{array}$ & -.525 & -2.864 & .329 & .048 & 18.943 & .005 \\
$\begin{array}{l}\text { Org Support } \\
\text { Som }\end{array}$ & & & & & & \\
\hline
\end{tabular}

Source: Research Data, 2020

At Step 1 of Table 4, job insecurity significantly predicted turnover intentions $(\beta=.426, p<.01)$, explaining $18.2 \%$ of the observed variance $\left(\mathrm{R}^{2}=.182, p<.01\right)$ in turnover intentions. When organizational support was entered at Step 2, it significantly predicted turnover intentions $(\beta=-.326, p<.01)$ accounting for an additional $9.9 \%$ of the elucidated variance in turnover intentions $\left(\mathrm{R}^{2}=.099, p<.01\right)$. The interaction (step 3) of job insecurity and Organizational support had a significantly effect on turnover intentions $(\beta=.525, p<.01)$ adding $4.8 \%$ of the expounded variance $\left(\mathrm{R}^{2}=.048, p<.01\right)$. This means that, the correlation between job insecurity and turnover intentions was moderated by organizational support. The second prediction which assumed that "organizational support moderates the relationship between job insecurity and turnover intention relationship" was supported.

Table 5: Hierarchical Regression showing Ethical Leadership as a moderator of the link between Job Insecurity and Turnover Intentions

\begin{tabular}{lcccccc}
\hline Steps & $\beta$ & $\mathrm{t}$ & $\mathrm{R}^{2}$ & $\Delta \mathrm{R}^{2}$ & $\mathrm{~F}$ & $p$ \\
\hline $\begin{array}{l}\text { Step 1 } \\
\text { Job Insecurity }\end{array}$ & .426 & 5.117 & .182 & .182 & 26.183 & .000 \\
$\begin{array}{l}\text { Step 2 } \\
\quad \text { Ethical Leadership }\end{array}$ & -.207 & -2.393 & .220 & .038 & 16.478 & .018 \\
$\begin{array}{l}\text { Step 3 } \\
\quad \text { Job Insecurity } \times\end{array}$ & & & & & & \\
$\begin{array}{l}\text { Ethical Leadership } \\
\text { Sthice }\end{array}$ & .511 & 3.170 & .282 & .062 & 15.186 & .002 \\
\hline
\end{tabular}

Source: Research Data, 2020

From the Step 1 of Table 5 , job insecurity positively predicted turnover intentions $(\beta=.426, p<.01)$, explaining $18.2 \%$ of the observed turnover intention variance $\left(\mathrm{R}^{2}=.182, p<.01\right)$. When entered in Step 2 of the model, ethical leadership significantly predicted turnover intentions $(\beta=-.207, p<.05)$ adding further $3.8 \%$ of the elucidating variance in turnover intentions $\left(\mathrm{R}^{2}=.038, p<.05\right)$. In step 3 , the interaction between job insecurity and ethical leadership significantly predicted turnover intentions $(\beta=.511, p<.01)$ accounting for an additional $6.2 \%$ of the expounded variance $\left(\mathrm{R}^{2}=.062, p<.01\right)$. This means that, the job insecurity-turnover intentions relationship was moderated by ethical leadership. The third prediction which assumed that "ethical leadership moderates the job insecurity and turnover intention relationship" was supported.

\section{Discussion}

The study aims to accomplish two objectives: To assess the relation between job insecurity and turnover intentions and to assess ethical leadership and organizational support as factors moderating the direct link between job insecurity and turnover intentions. 


\section{The link between Job Insecurity and Turnover Intentions}

The first hypothesis associated with the first objective, which proposed that job insecurity significantly predicts turnover intentions, was supported. This means that employees are more likely to decide to quit the organization when they perceive that their place in the organization is not secured. Thus, job insecurity is an essential element that fosters employee turnover intentions. The results corroborate the findings of other researches, which revealed that ethical leadership positively relates to employee commitment (Amponsah, 2015; Den Hartog \& De Hoogh, 2009; Lee \& Jeong, 2017). One reason for this association is that employees who perceive higher turnover intentions decide to leave because they do not want to be laid off. They, therefore, need to look for means of escaping the disgrace and psychological torture associated with being laid off (Lee \& Jeong, 2017).

Moreover, job insecurity is a subjective construct. Subjectivity comes from insecurity surrounding the security of the job in the future since insecure employees do not know if they will remain with the organization or lose their jobs. Due to this, they seek employment elsewhere or plan for their future within their current organization. This has the propensity to increase turnover intentions among employees. As indicated by Zhao et al. (2007), "to keep pace with the changing environment and cut down with the cost of higher turnover rate, organizations need to be flexible and improve insecurity surrounding the job environment to be able to sustain competitive advantage and ensure profitability in the long-run" (p. 12).

\section{Organizational Support Moderating Job Insecurity and Turnover Intentions Relationship}

Concerning the second objective, two hypotheses were formulated. Organizational support was first proposed to moderate the association between job insecurity and turnover intentions. This prediction was supported. This finding implies that job insecurity independently predicts turnover intentions, but the relationship is influenced by organizational support. Thus, higher social support reduces how job insecurity leads to turnover intentions. Lower organizational support will also increase the feeling of perceived insecurity leading to turnover intentions. This supports earlier researches which revealed that organizational support moderates the association between job insecurity and turnover intentions (Balz, \& Schuller, 2018; Gunalan \& Ceylan, 2015; Lim, 1996). This finding, however, contradicts the study by Bam (2010), which indicated that the nexus between job insecurity and turnover intention was not moderated by organizational support.

One reason that can be proffered to explain the underlying relationship is that support provided to employees by management makes employees feel part of the organization. When employees enjoy a high level of support, they conceive that their well-being is paramount to the management and that they are part of the organization's plans. In this case, insecurity will reduce, subsequently reducing the associated withdrawal behaviors such as turnover intentions. This suggests that managers need to provide high support to employees in a situation of high insecurity surrounding the job to decrease turnover intentions and the negative consequences associated with it.

\section{Moderating Role of Ethical Leadership in the Job Insecurity - Turnover Intentions Nexus}

Lastly, based on the second objective, it was also predicted that ethical leadership would moderate the association between job insecurity and turnover intentions. This prediction was also supported. This result has established that ethicality in leadership plays a central role in the association between job insecurity and turnover intentions. Thus, the association between perceived job insecurity and turnover intentions depends on how ethical the organizational leaders are. This finding corroborates existing literature that has shown the influential role of ethical leadership on the association between job insecurity and turnover intentions (Camgoz et al., 2016; Gyensare et al., 2015; Tatar \& Erdil, 2017). 
As proffered by Silla et al. (2010), ethical leadership augments employees' perception of the organization and related issues by making employees perceive fairness and value. The perception of fairness due to ethical leadership creates the impression that employees are secured in their positions. When leadership demonstrates ethicality in their relationship with subordinates, it influences subordinates to change their negative perceptions of the work context, reducing the associated withdrawal behavior such as turnover intentions (Gyensare et al., 2015). This finding suggests that leaders must be ethical and demonstrate productive organizational characteristics such as decency, altruism, fairness, selflessness, integrity, and respect for others to serve as role models that motivate employees to exhibit effective work behaviors.

\section{Limitations and Suggestions for Future Research}

This study has some limitations that need to be considered in future studies. One limitation is that the study was constrained to self-report measures. It did not give room for respondents to express themselves on the cause of insecurity and the reasons for the turnover. Additional studies employing open-ended questions will be beneficial. The second limitation has to do with the study's correlational nature, which makes it impossible to draw causality. Employing longitudinal data will help explain the causal relationship examined in this study.

Moreover, because the sampling method used was a non-probability sampling technique (convenience sampling), it failed to ensure that every member of the population had an equal chance of being part of the sample. Therefore, the interpretation must be made with caution. Lastly, the study restricts itself to quantitative measures that are limiting and are thus a disadvantage. Future studies can employ the mixed method, which will help provide more information on the underlying variables considered in this study. More studies on the moderating and mediating effects on the relationship between job insecurity and turnover intentions are recommended in the future.

\section{Managerial and Practical Implication}

This study offers noteworthy progressions for both stress and turnover research. Job insecurity is considered as stress associated with turnover intentions. The findings further extend the existing literature by indicating that ethical leadership and organizational support can mitigate the association between job insecurity and turnover intentions. Therefore, if organizations find it challenging to control the constant feeling of insecurity surrounding the job, the best remedy is for management to provide a higher level of support for employees.

The significant relationship between job insecurity and turnover intentions adds to the growing evidence and support for the moderating role of organizational support and ethical leadership in the underlying relationships. The finding of job insecurity predicting turnover intentions suggests that management should explicitly explain employees' job specifications and what they should expect from the organization. This would offer direction to organizations on reducing turnover intentions among employees in an organization. Moreover, leaders need to be ethical in their dealings to reduce the perception of job insecurity and prevent the relentless turnout intention among employees.

\section{Conclusion}

The study concludes that a negative correlation exists between job insecurity and turnover intentions. Also, organizational support moderated the association between job insecurity and turnover intentions. Moreover, the positive correlation between job insecurity and turnover intentions was moderated by ethical leadership. In volatile contemporary organizations, employees form the basis for almost all business dealings; therefore, increased attention is needed towards unique measures to reduce job insecurity and curtail turnover intentions. This can be done if managers are ethical in their dealing with employees and support employees in all capacities.

Funding: This research received no external funding. 
Conflicts of Interest: The authors declare no conflict of interest.

\section{References}

Acha, I. A. (2012). Microfinance Banking in Nigeria: Problems and Prospects. International Journal of Finance and Accounting, 1(5), 106-111.

Addai, P., Kyeremeh, E., Abdulai, W. \& Sarfo, J. O. (2008). Organizational Justice and Job Satisfaction as Predictors of Turnover Intentions among Teachers in the Offinso South District of Ghana. European Journal of Contemporary Education, 7(2), 235-243.

Addai, P., Ofori, I. N., Wiafe-Akenten, B. \& Tweneboah, D. N. (2018). Food Insecurity and Suicidal Tendencies: Comparative Study between Employed and Unemployed Graduates in the Greater Accra Region, Ghana. Journal of Education, Society and Behavioural Science, 24(1), 1-10.

Akosah, N. K., Lolohb, F. W., Lawson, N. \& Kumah, C. (2018). Measuring Financial Stability in Ghana: A New Index-Based Approach. Munich Personal RePEc Archive, 1 - 17.

Alghamdi, F. (2018). Job Insecurity, Organizational Commitment, Financial Responsibility, and Turnover Intention, a Test of Three-Way Interaction. International Business Research, 11(6), 213 - 225.

Allen, D., \& Shanock, L. (2013). Perceived organizational support and embeddedness as key mechanisms connecting socialization tactics to commitment and turnover among new employees. Journal of Organizational Behavior, 34(3), 11 - 23.

Amponsah, N. Y. K. (2015). The Impact of Perceived Organizational Politics and Job Security on Turnover Intentions among Workers of the Electricity Company of Ghana. Unpublished thesis submitted to University of Ghana, Legon, in partial fulfillment of the requirement for the award of MPhil psychology degree.

Amponsah-Tawiah, K., Annor, F. \& Arthur, B. G. (2015). Linking commuting stress to job satisfaction and turnover intention: The mediating role of burnout. Journal of Workplace Behavioral Health, 31(2), 104-123

Ashford, P., Lee, D. \& Bobko, P.R. (2001). Cross-cultural Psychology: Research and Applications. Cambridge: Cambridge University Press.

Attiah, N. G. \& AbouDahab, A. (2017). Investigating the factors affecting employee turnover intentions in the Educational Sector. The Business and Management Review, 8(5), 316 - 324

Balz, A., \& Schuller, K. (2018). Always looking for something better? The impact of job insecurity on turnover intentions: Do employables and irreplaceables react differently?. Economic and Industrial Democracy, 12, 24 $-36$

Bam, L. (2010). Job insecurity, job satisfaction, Organisational support and intention to leave of process controllers in a South African petrochemical company. Mini-dissertation submitted as partial fulfilment of the requirements for the degree Magister Artium in Industrial Psychology at the North-West University (Vaal Triangle Campus).

Baron, R. M. \& Kenny, D. A. (1986). The moderator-mediator variable distinction in social psychological research: Conceptual, strategic, and statistical considerations. Journal of Personality and Social Psychology, 51(6), 1173-1182.

Brown, M. E. \& Mitchell, M. S. (2010). Ethical and Unethical Leadership: Exploring New Avenues for Euture Research. Business Ethics Quarterly, 20(4), 583-616.

Ekmekci, O. T. \& Karapinar, P. B. (2015). Job Insecurity and Turnover Intentions: Gender Differences and the Mediating Role of Work Engagement. Sex Roles, 75, 11 - 12.

Cammann, C., Fichman, M., Jenkins, D. \& Klesh, J. (1979). The Michigan Organizational Assessment Questionnaire. Unpublished Manuscript, University of Michigan, Ann Arbor, MI.

Cascio, W.F. (1999). Learning from outcomes: Financial experiences of 311 firms that have downsized', In M.K. Gowing, J.D. Kraft, \& J.C. Quick (Eds.), The new organizational reality: Downsizing, restructuring, and revitalization, American Psychological Association, Washington.

De Cuyper, M. \& De Witte, R. (2006). The Internal Control Index: A Newly Developed Measure of Locus of Control. Educational and Psychological Measurement, 44, 209 - 21. 
Den Hartog, D., \& De Hoogh, A. H. (2008). Ethical and Despotic Leadership, Relationships with Leader's Social Responsibility: A Multi-Method Study. The Leadership Quarterly, 19, 297-31

Dinc, M. S. \& Nurovic, E. (2016). The Impact of Ethical Leadership on Employee Attitudes in Manufacturing Companies. Nile Journal of Business and Economics, 3, 3-14

Dwomoh, G. \& Frempong, E. (2017). Factors Influencing Employees' Retention in the Banking Industry of Ghana. Review of Public Administration and Management, 5(3), 1 - 7

Eisenberger, R., Armeli, S., Rexwinkel, B., Lynch, P. D. \& Rhoades, L. (2001). Reciprocation of perceived organizational support. Journal of Applied Psychology, 86(1), 42.

Eisenberger, R., Huntington, R., Hutchison, S., \& Sowa, D. 1986. Perceived organizational support. Journal of Applied Psychology, 71: $500-507$

Gellis, M. \& Kim, P. (2004). Intention of Leaving the Organization. Academy of Management Journal, 35(3), 626637

Gunalan, M. \& Ceylan, A. (2015). The Mediating Effect of Organizational Support between Job Insecurity and Turnover Intention in Private Hospitals. International Journal of Business and Management, 10(10), 74.

Gyensare, M. A., Otoo, E. A., Asareb, J. \& Twumasi, E. (2015). Antecedents and consequence of employee turnover intention: Empirical evidence from Ghana. Management Science Letters, 5, 781-796

Jimenez, P., Milfelner, B., Sarotar, S., \& Dunkl, A. (2017). Moderating Effects between Job Insecurity and Intention to Quit in Samples of Slovene and Austrian Workers. Naše gospodarstvo/Our Economy, 63(1), $27-37$.

Lee, S. H. \& Jeong, D. Y. (2017). Job insecurity and turnover intention: Organizational commitment as mediator. Social Behavior and Personality: an international journal, 45(4), 529-536

Lim, V. K. G. (1996). Job Insecurity and Its Outcomes: Moderating Effects of Work-Based and NonworkBased Organisational support. Human Relations 49(2), 171-194

Northouse, P. (2013). Leadership Theory and Practice (6 $6^{\text {th }}$ Ed.). Thousand Oaks: CA, SAGE Publications, Inc.

Ofori, E. (2020). The effects of Ponzi schemes and revocation of licences of some financial institutions on financial threat in Ghana. Journal of Financial Crime. 12, $14-24$.

Okyere-Kwakye, E., Nor, K. M., Assampong, I. E.-, \& Awang, S. R. (2018). Employees’ Turnover: Examining its Causes in the Ghanaian Banking Industry. International Journal of Academic Research in Business and Social Sciences, 8(2), 349-362.

Osei Boakye, A., Dei Mensah, R., Bartrop-Sackey, M., \& Muah, P. (2021). Juggling between

work, studies and motherhood: The role of social support systems for the attainment of work-life

balance. SA Journal of Human Resource Management, 19, 10 pages.

Puni, A., Mohammed, I., \& Asamoah, E. (2018). Transformational leadership and job satisfaction: the moderating effect of contingent reward. Leadership and Organization Development Journal, 39(4), 522-537

Rousseau, D. M. (2009). Psychological Contract Inventory Technical Report. Pittsburgh, PA: Heinz School of Public Policy, Carnegie Mellon University.

Rousseau, D. M. (2011). The individual-organisation relationship: The employee trust. In S. Zedeck (ed.), Handbook of industrial and organisational psychology (Vol. 3, pp. 191-220). Washington, DC: American Psychological Association.

Rubin, R., Dierdoff, E., \& Brown, M. (2010). Do Ethical Leaders Get Ahead? Exploring Ethical Leadership and promotability. Business Ethics Quarterly, 20 (2), 215-236.

Shore, L. M., \& Wayne, S. J. (1993). Commitment and employee behavior: Comparison of affective commitment and continuance commitment with perceived organizational support. Journal of Applied Psychology, 78, 774-780.

Silla, I., Gracia, J. F., Rodriguez, M. A. \& Peiro, J. M. (2010). Job insecurity and employees' attitudes: The moderating role of fairness. International Journal of Manpower, 4, 449-465 
Sverke, M., \& Hellgren, J. (2002). The nature of job insecurity: Understanding employment uncertainty on the brink of a new millennium. Applied Psychology: An International Review, 51, $23-42$.

Tabachnick, B. G. \& Fidell, L. S (1996). Multivariate analysis (3rd edition). HarperCollins College Publishers (New York, NY)

Tatar, B. \& Erdil, O. (2017). Delineating the impact of organizational dissent on job insecurity and turnover intention Conference: 7th International Conference on Leadership, Technology, Innovation, and Business Management

Trimble, D. E. (2006). Organizational commitment, job satisfaction, and turnover intention of missionaries. Journal of Psychology and Theology, 34, 349-360.

Wayne, S. J., Shore, L. M., \& Liden, R. C. (1997). Perceived organizational support and leader-member exchange: A social exchange perspective. Academy of Management Journal, 40(1), 82-111.

Zhao, H., Wayne, S., Glibkowski, B. C., \& Bravo, J. (2007). The Impact of Psychological Contract Breach on Work-Related Outcomes: A Meta-Analysis. Personnel Psychology, 60(3), 647-680 